\title{
Mesquite Extract as Phytogenic Additive to Improve the Nutrition of Sheep
}

\author{
Renato Tonhá Alves Júnior ${ }^{2}$, Evaristo Jorge Oliveira de Souza ${ }^{1}$, Airon Aparecido Silva de $\mathrm{Melo}^{2}$, \\ Dulciene Karla de Andrade Silva ${ }^{2}$, Thaysa Rodrigues Torres ${ }^{1}$, Gerfesson Felipe Cavalcanti Pereira ${ }^{1}$, \\ Camila Sousa da Silva ${ }^{1} \&$ José Ricardo Coelho da Silva ${ }^{2}$ \\ ${ }^{1}$ Academic Unit of Serra Talhada, Federal Rural University of Pernambuco, Serra Talhada, Brazil \\ ${ }^{2}$ Academic Unit of Garanhuns, Federal Rural University of Pernambuco, Garanhuns, Brazil \\ Correspondence: Evaristo Jorge Oliveira de Souza, Academic Unit of Serra Talhada, Federal Rural University of \\ Pernambuco, Serra Talhada, Pernambuco 56909-535, Brazil. Tel: 55-087-3929-3010. E-mail: \\ evaristo.souza@ufrpe.br
}

Received: April 25, 2017

Accepted: May 26, 2017 Online Published: June 15, 2017

doi:10.5539/jas.v9n7p164

URL: https://doi.org/10.5539/jas.v9n7p164

\begin{abstract}
Four concentrations $(0,200,400,600$ and $800 \mathrm{mg}$ extract per $\mathrm{ml}$ of water) of mesquite extract were used as phytogenic additive to verify the potential to increase the nutritional value of the feed, ruminal parameters (primarily propionate production) and nitrogen use efficiency, microbial protein synthesis and quantify the reduction of ciliated protozoa and characterize the ingestive behavior of sheep. Ten adult male sheep were subjected to a $5 \times 5$ double Latin square design. Prior to feeding, the animals received the mesquite extract. Nutrient intake was estimated from the difference of the amount of feed provided and the total surplus. Rumen content samples were collected to evaluate the profile of short-chain fatty acids, ammonia nitrogen, $\mathrm{pH}$, ciliated protozoa, turnover rate and disappearance rate. To estimate the microbial protein synthesis, the technique of purine derivatives was used. The mesquite extract quadratically increased $(P<0.05)$ the digestibility of dry matter, organic matter, crude protein and total digestible nutrients, as well as increased propionate production, acetate:propionate ratio and microbial protein synthesis. The numbers of ciliate protozoa in the rumen decreased as a result of mesquite extract inclusion in the diet. The use of mesquite pod extract at a concentration of $488 \mathrm{mg} / \mathrm{mL}$ is recommended to improve digestibility of dry matter, organic matter, crude protein and total digestible nutrients, and to optimize microbial protein synthesis and increase propionic acid production.
\end{abstract}

Keywords: bioactive compounds, natural drugs, short-chain fatty acids, small ruminants, tannins

\section{Introduction}

For decades, growth-promoting antibiotics known as ionophores, have been used in the diet of ruminants to promote increased production and feed conversion, and to reduce diseases. Their impacts on performance are attributed to the manipulation of microorganisms responsible for ruminal fermentation from the control of bacteria, especially those that are Gram-positive (Carvalho et al., 2017; Castillejos, Calsamiglia, Martín-Tereso, \& Wijlen, 2008).

Although representing an innovation in terms of improving animal performance, the inclusion of ionophores in the diet increases feed cost and is condemned by many consumer groups, government institutions and research centers, which adopt the banning or the substitution of synthetic drugs commonly used in animal production aiming to keep the final product free from any toxicity (Nisbet, Callaway, Edrington, Anderson, \& Krueger, 2009; Oskoueian, Abdullah, \& Oskoueian, 2013). Due to this restriction, alternatives to ionophores have been sought. Thus, the use of plant bioactive compounds as additives in ruminant feed (phytogenic additives) becomes an alternative means for improving animal performance that is unrestricted by most markets of animal products.

Bodas et al. (2012), Durmic and Blache (2012), and Flachowsky and Lebzien (2012) reported that bioactive compounds produced through secondary metabolism in plants have the ability to affect rumen microorganisms, including protozoa, fungi and gram-positive bacteria. Therefore it is possible that these compounds can be used to optimize ruminal fermentation. Although gram-positive bacteria are very important for the fermentation of structural carbohydrates (cellulose and hemicellulose), gram-negative bacteria increase their population 
proportionally, and consequently decrease the acetate:propionate ratio, while increasing the microbial protein supply to the ruminant animal; Other benefits such as energy utilization and greater dietary protein supply to the animal also exist (Durmic \& Blache, 2012).

Using synthetic additives for animal production in the semi-arid region of Northeast Brazil is unfeasible, not only from the financial point of view, but also logistic. In this sense, there is an opportunity to use plants such as Mesquite (Prosopis juliflora (Sw.) DC.). They are rich in secondary compounds, whose mode of action on ruminal fermentation is very similar to that of synthetic additives. These compounds also have the advantage of not imparting residues into the final products of animals that consume them. As a result, the use of mesquite represents a viable alternative because it is widespread in the Brazilian semi-arid region and is therefore very well adapted to the climate. It is capable of fruiting in the dry season, producing pods that can be used as a source of secondary compounds for phytogenic additive preparation.

Mesquite (Prosopis juliflora (Sw.) DC.) produces compounds that can be used as manipulators of ruminal fermentation, as they exhibit antibacterial, antioxidant, antifungal, antihelminthic and antitumor activity (William \& Jafri, 2015). As a result of these activities, they optimize propionate production, decrease the deamination of dietary amino acids, reduce methanogenic bacteria, increase the protein flow to the small intestine and improve digestibility of the diet. Among the secondary compounds found in mesquite, the tannins are highlighted, which despite having negative effects on nutrition, present specific antibacterial action, mainly on Gram-positive bacteria.

The condensed tannins are capable of complexing with enzymes, causing changes in the microbial metabolism (Bodas et al., 2012). They also inhibit the action of cellulolytic and proteolytic bacteria by reducing ruminal proteolysis. Because they bind with dietary proteins their degradation is slower in the rumen, due in part to the difficulty that microbes have acting upon these tannin-protein complexes (Durmic et al., 2008; Morales \& Ungerfeld, 2015). Moreover, the condensed tannins bind to the membranes of protozoa causing their death, resulting in lower predation of Gram-negative bacteria and thereby better fermentation of nutrients in the rumen (Bodas et al., 2012; Patra \& Saxena, 2011). Patra and Saxena (2011) reported that states that although tannins reduce the availability of nutrients, they cause changes in the partition of nutrients, leading to a greater proportion of nutrients available for microbial synthesis and a lower proportion for the production of short-chain fatty acids.

The objective of this study was to evaluate the use of mesquite extract as a phytogenic additive on intake, digestibility, ingestive activity, ruminal parameters, nitrogen use efficiency, microbial protein synthesis and ciliated protozoa in the rumen of sheep.

\section{Materials and Methods}

This study was carried out in strict accordance with the recommendations of the Guide of the National Council for the Control of Animal Experimentation (CONCEA). The protocol was approved by the Committee on the Ethics of Animal Experiments of the Federal Rural University of Pernambuco, Pernambuco State, Brazil (approval no. 005/2014).

\subsection{Experiment site, Animals and Feed}

The experiment was carried out from January to March 2014, in the Academic Unit of Serra Talhada ("Unidade Acadêmica de Serra Talhada, UAST") of the Federal Rural University of Pernambuco ("Universidade Federal Rural de Pernambuco, UFRPE”; $07^{\circ} 59^{\prime} 31^{\prime \prime} \mathrm{S}$ and $38^{\circ} 17^{\prime} 54^{\prime \prime} \mathrm{W}$ ). This location has a semiarid climate and annual rainfall of approximately $400 \mathrm{~mm}$. During the experiment, rainfall was $7.28 \mathrm{~mm}$ and the average temperature was $30^{\circ} \mathrm{C}$ (National Institute of Meteorology [INMET], 2014). Ten adult male sheep of no defined breed (five of those fitted with rumen cannula) with an average body weight of $47.6 \pm 4.89 \mathrm{~kg}$ were used. The experiment lasted 90 days, which were divided into five 18-day periods, of which seven days was for animal acclimation to the experimental diets and 11 for data collection. The animals were treated for internal and external parasites by administration of doramectin $\left(\right.$ DECTOMAX $\left.{ }^{\circledR}\right)$ prior the beginning of the experiment. The animals were housed in individual $2 \times 2 \mathrm{~m}$ pens, equipped with an individual feeder and water trough.

The feed was composed of 117.21 and $637.64 \mathrm{~g} / \mathrm{kg}$ crude protein and total digestible nutrients, respectively, and consisted of Tifton 85 grass hay, ground corn, soybean meal, urea, ammonium sulfate and mineral mixture (Table 1). The animals were fed the complete ration twice a day (9:00 and 16:00) and the amount fed was adjusted daily according to the previous day's consumption, allowing orts of $10 \%$. 
Table 1. Proportions of ingredients in the feed

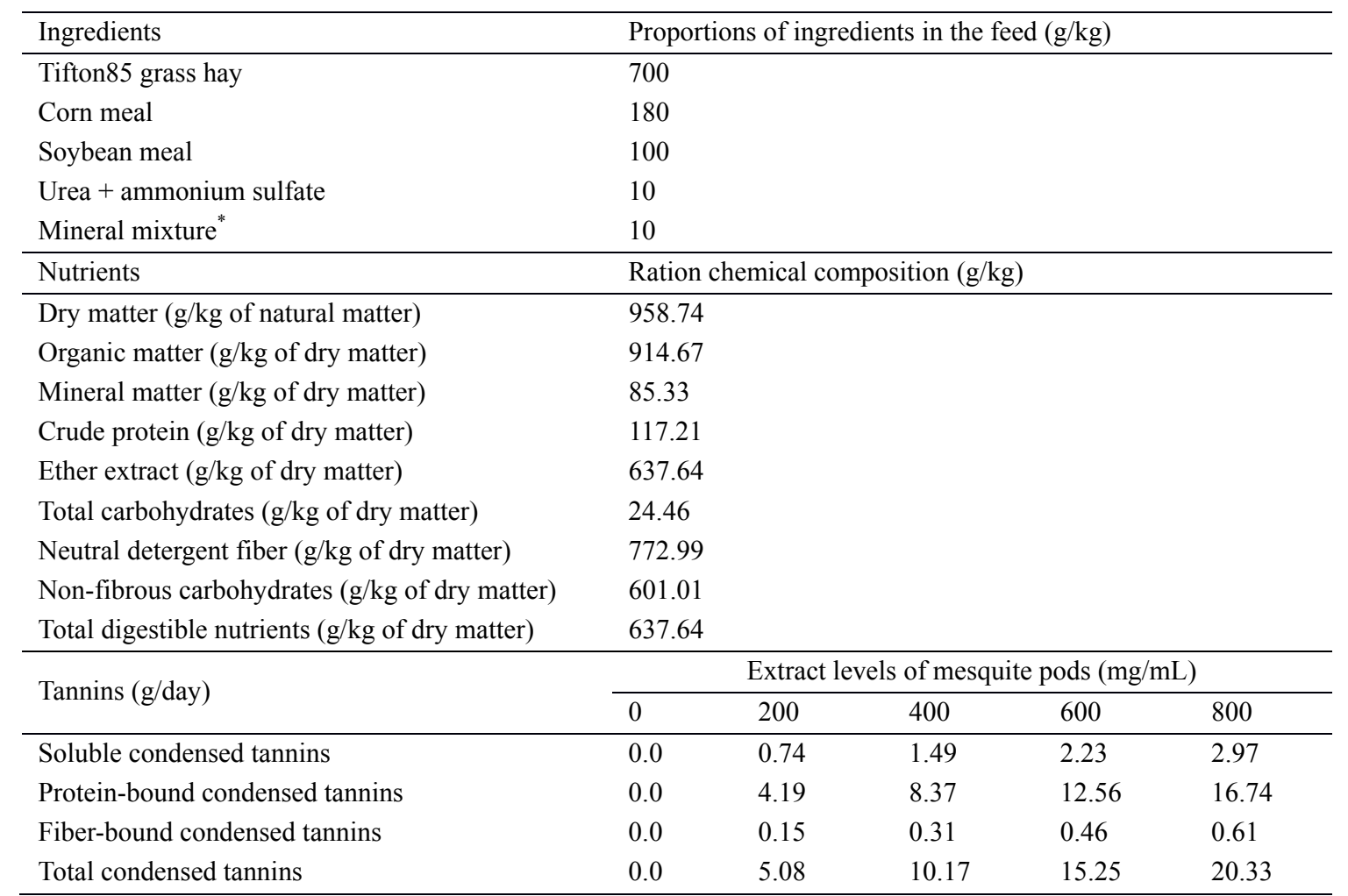

Note. ${ }^{*}$ Composition of the mineral mixture (nutrients $/ \mathrm{kg}$ of product): $\mathrm{Ca}=140 \mathrm{~g} / \mathrm{kg} ; \mathrm{P}=70 \mathrm{~g} / \mathrm{kg} ; \mathrm{Mg}=1.320$ $\mathrm{mg} / \mathrm{kg} ; \mathrm{Fe}=2.200 \mathrm{mg} / \mathrm{kg} ; \mathrm{Co}=140 \mathrm{mg} / \mathrm{kg} ; \mathrm{Mn}=3.690 \mathrm{mg} / \mathrm{kg} ; \mathrm{Zn}=4.700 \mathrm{mg} / \mathrm{kg} ; \mathrm{I}=61 \mathrm{mg} / \mathrm{kg} ; \mathrm{Se}=45 \mathrm{mg} / \mathrm{kg}$; $\mathrm{S}=12 \mathrm{~g} / \mathrm{kg} ; \mathrm{Na}=148 \mathrm{~g} / \mathrm{kg} ; \mathrm{F}=700 \mathrm{mg} / \mathrm{kg}$.

\subsection{Experimental Treatments}

The treatments consisted of $6 \mathrm{~mL}(3 \mathrm{~mL}$ prior to the first feeding and $3 \mathrm{~mL}$ prior to the second feeding) of five concentrations $(0,200,400,600$, and $800 \mathrm{mg} / \mathrm{mL}$ water) of mesquite pod extract, provided orally with a syringe.

To obtain the aqueous extract from the mesquite pods, 20, 40, 60 and $80 \mathrm{~g}$ of the material (mesquite pods) were weighed on a semi-analytical balance, macerated and diluted in $100 \mathrm{~mL}$ of boiling distilled water at $100{ }^{\circ} \mathrm{C}$. Subsequently, the crude extract was stored in airtight containers for 40 minutes and labeled with the concentrations of $0,200,400,600$ and $800 \mathrm{mg}$ extract $/ \mathrm{ml}$ of water, respectively, for obtaining the extract.

\subsection{Intake Determination and Nutrient Digestibility}

Dry matter intake (DMI) and other nutrients were estimated by the difference between the amount of feed provided and the total surplus. Fecal dry matter production was determined by total feces collection. In this procedure, collection bags made from unbleached cotton coated with napa were utilized. The nutrient digestibility was calculated according to the quantity of nutrient absorbed, by taking the value of excreted nutrient divided by the value of ingested nutrient.

For three consecutive days of the collection period, samples from Tifton 85 grass hay, ground corn, soybean meal, mineral mix, orts and feces were collected, which were weighed, placed in plastic bags previously identified and stored in a freezer at $-20^{\circ} \mathrm{C}$. Subsequently, samples consisting of period and treatment were made. All samples were dried in a forced air oven at $55 \pm 5^{\circ} \mathrm{C}$ for 72 hours and ground in a Wiley mill to pass through sieves with $1 \mathrm{~mm}$ diameter mesh for analysis of dry matter (DM) (method 967.03), mineral matter (MM) (method 942.05), and crude protein (CP) (method 988.05), following recommendations of the AOAC (1990). The neutral detergent fiber (NDF) was determined according to Van Soest, Robertson and Lewis (1991) using alpha-amylase as recommended by AOAC (1990). The ether extract (method 920.29) was determined using an ANKOM XT-15 Extractor, in which extraction was conducted at a temperature of $90{ }^{\circ} \mathrm{C}$ in a closed system for 60 minutes, using hexane as an organic solvent. The equations proposed by Sniffen, O’Connor, Van Soest, Fox 
and Russell (1992), Hall (2000) and Weiss (1999) were used to estimate total carbohydrates, non-fibrous carbohydrates and total digestible nutrients (TDN), respectively.

\subsection{Ingestive Behavior}

The ingestive behavior was assessed by simultaneous observation of animals by the punctual instant sweep method every five minutes over a 24-hour period. An observer was used for each animal to increase the observation efficiency and take notes of data individually. The following activities were observed: total feeding, rumination, chewing (sum of total feeding time plus total rumination time) and idle time. With these data it was possible to determine feed efficiency and rumination efficiency:

Feed efficiency in DM = DM intake (kg/day)/feeding time (min/day);

Feed efficiency in NDF $=$ NDF intake ( $\mathrm{kg} /$ day)/feeding time (min/day);

Rumination efficiency in $\mathrm{DM}=\mathrm{DM}$ intake $(\mathrm{kg} /$ day)/rumination time (min/day) and Rumination efficiency in $\mathrm{NDF}=\mathrm{NDF}$ intake $(\mathrm{kg} /$ day $) /$ rumination time $(\mathrm{min} /$ day $)$.

\subsection{Determination of the Ruminal Parameters}

Rumen content samples $( \pm 300 \mathrm{ml})$ were manually collected from four different points in the ventral region of the rumen, after the homogenization of the rumen content. The first sample was taken before feeding, at $09 \mathrm{~h} 00$, with subsequent samples taken at the following times: $0,1,2,3,4,5,6,7,8,9,10$, and 11 hours after feeding. The content was filtered through four layers of cheesecloth, then the solid part was returned to the rumen, the liquid was immediately homogenized and the $\mathrm{pH}$ was measured by direct reading with a digital potentiometer (Handylab 1-SCHOTT).

After measuring the $\mathrm{pH}$, a $20 \mathrm{~mL}$ aliquot was packed in a glass bottle containing one milliliter of hydrochloric acid $(6 \mathrm{~N})$ and stored at $-20{ }^{\circ} \mathrm{C}$ for determination of ruminal short-chain fatty acids (SCFA) and ammonia nitrogen $\left(\mathrm{N}-\mathrm{NH}_{3}\right)$. Ruminal SCFA (i.e., acetic, propionic and butyric acids) were determined using a gas chromatograph (GC-Master, GC Analitica, Ltda, Brazil) equipped with a $30 \mathrm{~m}$ corbowax 20Mfused silica capillary column. Column temperature was fixed at $150{ }^{\circ} \mathrm{C}$ for a run time of two min. Injector and detector temperatures were $250{ }^{\circ} \mathrm{C}$ and $270{ }^{\circ} \mathrm{C}$, respectively. Gas flows were 30,300 , and $25 \mathrm{ml} / \mathrm{min} \mathrm{for} \mathrm{He}$, air and $\mathrm{H}_{2}$, respectively. Isocaproic acid was used as an internal standard. For the determination of $\mathrm{N}^{-\mathrm{NH}_{3}}$, the samples were thawed and centrifuged at $3000 \mathrm{rpm}$ for 15 minutes, according to the technique described by Fenner (1965).

The total rumen content and the ruminal fluid density were calculated by the technique of complete emptying of the rumen, before the first feeding (time zero) and four hours after. 500-g samples were collected for subsequent analysis of dry matter (DM) (method 967.03) and crude protein (CP) (method 988.05), following recommendations of the AOAC (1990), and NDF according to Van Soest et al. (1991). The turnover rate $(\mathrm{kg} / \mathrm{h})$ and the disappearance rate of rumen content (h) were calculated according to Cannas, Van Soest and Pell (2003), taking into account the DM, NDF and CP.

\subsection{Nitrogen Use Efficiency and Estimation of Microbial Protein Synthesis}

Total excreted urine over a 24-h period was used to determine the nitrogen use efficiency and estimate the microbial protein synthesis. Samples were collected with the help of funnels fixed in the animals, and the urine was collected in a carboy, which contained $100 \mathrm{ml}$ of $40 \% \mathrm{v} / \mathrm{v}$ sulfuric acid $\left(\mathrm{H}_{2} \mathrm{SO}_{4}\right)$. The samples were $\mathrm{pH}$ adjusted, when necessary, to values below three, with small drops of concentrated sulfuric acid, to prevent the bacterial destruction of purine bases in the urine and the precipitation of uric acid.

After measuring the total amount of urine, a 10-ml sample was separated, centrifuged at $2000 \times \mathrm{g}$ for 20 minutes at $4{ }^{\circ} \mathrm{C}$ and frozen at $-20{ }^{\circ} \mathrm{C}$ for further analysis. Urine samples were analyzed for total nitrogen by the Kjeldahl method, according to the methodology described by method 988.05 (AOAC, 1990). The nitrogen use efficiency (NE) was calculated considering the amount of nitrogen offered less the sum of nitrogen on the remains, feces and urine: $\mathrm{NE}=$ Nitrogen intake $-($ Nitrogen on the feces + Nitrogen on the urine).

The purine derivatives (i.e., allantoin, xanthine, hypoxanthine and uric acid) were determined according to Chen and Gomez (1992). The amount of absorbed microbial purine ( $\mathrm{X} \mathrm{mmol} / \mathrm{day}$ ) corresponding to the purine derivatives excreted ( $\mathrm{Ymmol} / \mathrm{day}$ ) was calculated according to Chen and Gomez (1992):

$$
\mathrm{Y}=0.84 \mathrm{X}+\left(0.15 \mathrm{BW}^{0.75} e^{-0.25} \mathrm{X}\right)
$$

Where, BW is the body weight, and 0.84 the recovery of purines absorbed as purine derivatives in the urine. The microbial nitrogen supplied to the small intestine was calculated from the absorbed microbial purine (X) according to the equation of Chen and Gomez (1992): 


$$
\text { Microbial N }(\mathrm{g} / \text { day })=(70 \mathrm{X}) /(0.83 \times 0.116 \times 1000)
$$

Where, 70 represents the content of $\mathrm{N}$ in the purines $(\mathrm{mgN} / \mathrm{mmol})$, and 0.83 the digestibility of microbial purines.

\subsection{Count of Ciliated Protozoa in the Rumen}

The count of ciliated protozoa in the rumen was performed according to the technique described by Dehority (1984). For this, four hours after feeding, $10 \mathrm{ml}$ of rumen fluid filtered through cheesecloth were collected and preserved in $10 \mathrm{ml}$ of $18.5 \%$ formalin. The quantification of ciliate genera was performed in a Sedgewick-Rafter chamber, according to Dehority (1984), with modifications proposed by D'agosto and Carneiro (1999).

\subsection{Determination of the condensed Tannins Extraction}

The extraction of the tannins of the mesquite pod was made according to Terrill, Rowan, Douglas and Barry (1992), which uses purification standards for the analysis of condensed tannins (Table 1).

\subsection{Experimental Design and Statistical Analysis}

The experiment was analyzed in a double balanced Latin square design. Data related to intake $(\mathrm{n}=10)$, nutrient digestibility $(n=10)$, feeding behavior $(n=10), N$ balance $(n=10)$ and ruminal parameters $(n=5$, only fistulated animals) underwent analysis of variance for a double Latin square using the GLM procedure of the SAS package, version 9.1 (SAS, 2009), with the following model:

$$
\mathrm{Y}_{\mathrm{ijk}}=\mu+\mathrm{T}_{\mathrm{i}}+\mathrm{P}_{\mathrm{j}}+\mathrm{C}_{\mathrm{k}}+\mathrm{e}_{\mathrm{ijk}}
$$

Where, $Y_{i j k}$ is the observation, $\mu$ is the average popuation, $T_{i}$ is the treatment, $P_{j}$ stands for the period, $C_{k}$ is the random effect of the animal, and $\mathrm{e}_{\mathrm{ijk}}$ is the residual error. Data related to ruminal $\mathrm{pH}$, ammonia- $\mathrm{N}$ and SCFA $(\mathrm{n}=$ 5 , only fistulated animals) were analyzed as repeated measures using the SAS PROC MIXED procedure, with the following model:

$$
\mathrm{Y}_{\mathrm{ijk}}=\mu+\mathrm{T}_{\mathrm{i}}+\mathrm{P}_{\mathrm{j}}+\mathrm{C}_{\mathrm{k}}+\mathrm{S}_{\mathrm{j}}+\mathrm{T}_{\mathrm{i}} \mathrm{S}_{\mathrm{j}}+\mathrm{e}_{\mathrm{ijk}}
$$

Where, $Y_{i j k}$ is the observation, $\mu$ is the average population, $T_{i}$ is the treatment, $P_{j}$ stands for the period, $C_{k}$ is the random effect of the animal, $S_{j}$ is the collection time, $T_{i} S_{j}$ is the interaction between treatment and collection time, and $\mathrm{e}_{\mathrm{ijk}}$ is the residual error. The comparisons between the different concentrations of the mesquite extract were conducted by decomposing the treatment sum of squares into contractions relative to the linear, quadratic and cubic effects, with subsequent adjustment of regression equations. Contrast analysis was performed on CONTRAST-encoded SAS. The carryover effects were tested on the SAS-encoded CARRY. The standard error of the mean was obtained from original data. Treatment effects were considered significant when $P<0.05$.

\section{Results}

\subsection{Nutrient Intake, Digestibility and Ingestive Behavior}

The use of mesquite extract resulted in no significant effect $(P>0.05)$ on dry matter intake (DMI), organic matter (OM), neutral detergent fiber (NDF), non-fibrous carbohydrates (NFC), crude protein (CP) and total digestible nutrients (TDN). Additionally, there was no change in total rumination, chewing and idle time or in the feeding and rumination efficiencies (Table 2). The digestibility of dry matter, organic matter, crude protein and total digestible nutrients had a quadratic effect $(P<0.05)$ with the addition of the extract, showing maximum response when the extract was provided in the concentrations of 502, 482, 458 and $466 \mathrm{mg} / \mathrm{ml}$. There was no effect $(P>0.05)$ on the digestibility of NDF and NFC (Table 2$)$. 
Table 2. Nutrient intake, digestibility and animal behavior of sheep fed increasing levels of mesquite pods extract

\begin{tabular}{|c|c|c|c|c|c|c|c|c|c|c|}
\hline \multirow{2}{*}{ Items } & \multicolumn{5}{|c|}{ Extract levels of mesquite pods $(\mathrm{mg} / \mathrm{mL})$} & \multirow{2}{*}{ S.E.M. } & \multirow{2}{*}{$\hat{\mathrm{Y}}$} & \multicolumn{3}{|c|}{ Polynomial contrasts } \\
\hline & 0 & 200 & 400 & 600 & 800 & & & $\mathrm{~L}$ & Q & $\mathrm{C}$ \\
\hline \multicolumn{11}{|l|}{ Dry matter } \\
\hline Intake (kg/day) & 1.22 & 1.35 & 1.33 & 1.34 & 1.29 & 0.043 & 1.31 & 0.32 & 0.37 & 0.60 \\
\hline Digestibility $(\mathrm{g} / \mathrm{kg})$ & 666 & 709 & 713 & 711 & 685 & 0.790 & {$[1]$} & 0.48 & 0.03 & 0.98 \\
\hline \multicolumn{11}{|l|}{ Organic matter } \\
\hline Intake (kg/day) & 1.12 & 1.24 & 1.22 & 1.22 & 1.18 & 0.040 & 1.20 & 0.33 & 0.37 & 0.58 \\
\hline Digestibility $(\mathrm{g} / \mathrm{kg})$ & 685 & 725 & 729 & 726 & 700 & 0.756 & [2] & 0.54 & 0.03 & 0.91 \\
\hline \multicolumn{11}{|c|}{ Neutral detergent fiber } \\
\hline Intake (kg/day) & 0.69 & 0.78 & 0.76 & 0.77 & 0.75 & 0.026 & 0.75 & 0.30 & 0.37 & 0.33 \\
\hline Digestibility (g/kg) & 630 & 651 & 654 & 656 & 619 & 1.345 & 642 & 0.86 & 0.30 & 0.62 \\
\hline \multicolumn{11}{|c|}{ Non-fibrous carbohydrates } \\
\hline Intake (kg/day) & 0.23 & 0.25 & 0.24 & 0.25 & 0.24 & 0.008 & 0.24 & 0.59 & 0.60 & 0.56 \\
\hline Digestibility $(\mathrm{g} / \mathrm{kg})$ & 864 & 949 & 939 & 934 & 943 & 1.917 & 926 & 0.27 & 0.37 & 0.43 \\
\hline \multicolumn{11}{|l|}{ Crude protein } \\
\hline Intake (kg/day) & 0.16 & 0.17 & 0.16 & 0.17 & 0.16 & 0.005 & 16.4 & 0.57 & 0.59 & 0.64 \\
\hline Digestibility (g/kg) & 730 & 765 & 787 & 779 & 738 & 1.077 & {$[3]$} & 0.69 & 0.04 & 0.55 \\
\hline \multicolumn{11}{|c|}{ Total digestible nutrientes } \\
\hline Intake (kg/day) & 0.79 & 0.86 & 0.91 & 0.91 & 0.86 & 0.035 & 86.6 & 0.20 & 0.27 & 0.69 \\
\hline Digestibility $(\mathrm{g} / \mathrm{kg})$ & 637 & 677 & 680 & 677 & 653 & 0.734 & {$[4]$} & 0.53 & 0.03 & 0.92 \\
\hline \multicolumn{11}{|l|}{ Feeding behavior } \\
\hline Rumination (min) & 513 & 561 & 529 & 528 & 526 & 12.09 & 531 & 0.98 & 0.53 & 0.13 \\
\hline Feeding (min) & 309 & 280 & 282 & 290 & 282 & 6.82 & 289 & 0.34 & 0.42 & 0.12 \\
\hline Chewing (min) & 822 & 841 & 811 & 818 & 808 & 13.07 & 820 & 0.60 & 0.87 & 0.47 \\
\hline Idleness (min) & 618 & 599 & 629 & 622 & 632 & 13.07 & 620 & 0.60 & 0.87 & 0.46 \\
\hline $\mathrm{FEF}_{\mathrm{DM}}(\mathrm{g} / \mathrm{min})$ & 4.69 & 4.34 & 4.98 & 4.77 & 4.03 & 0.182 & 4.56 & 0.39 & 0.35 & 0.12 \\
\hline $\mathrm{FEF}_{\mathrm{NDF}}(\mathrm{g} / \mathrm{min})$ & 2.66 & 2.59 & 2.84 & 2.75 & 2.32 & 0.107 & 2.63 & 0.44 & 0.28 & 0.20 \\
\hline $\mathrm{REF}_{\mathrm{DM}}(\mathrm{g} / \mathrm{min})$ & 2.44 & 2.47 & 2.32 & 2.76 & 2.22 & 0.106 & 2.44 & 0.75 & 0.57 & 0.14 \\
\hline $\mathrm{REF}_{\mathrm{NDF}}(\mathrm{g} / \mathrm{min})$ & 1.39 & 1.45 & 1.32 & 1.58 & 1.28 & 0.064 & 1.40 & 0.85 & 0.54 & 0.24 \\
\hline
\end{tabular}

Note. S.E.M. $=$ Standard error mean; $\mathrm{FEF}_{\mathrm{DM}}=$ Feed efficiency in dry matter; $\mathrm{FEF}_{\mathrm{NDF}}=$ Feed efficiency in neutral detergent fiber; $\mathrm{REF}_{\mathrm{DM}}=$ Rumination efficiency in dry matter; $\mathrm{REF}_{\mathrm{NDF}}=$ Rumination efficiency in neutral detergente fiber; $\mathrm{L}=$ Linear; $\mathrm{Q}=$ Quadratic; $\mathrm{C}=\mathrm{Cubic} ;{ }^{[l]} \hat{\mathrm{Y}}=-0.0002 \mathrm{x}^{2}+0.2006 \mathrm{x}+670.09, \mathrm{R}^{2}=0.88 ;{ }^{[2]} \hat{\mathrm{Y}}=$ $-0.0002 \mathrm{x}^{2}+0.1929 \mathrm{x}+688.51, \mathrm{R}^{2}=0.91 ;{ }^{[3]} \hat{\mathrm{Y}}=-0.0003 \mathrm{x}^{2}+0.275 \mathrm{x}+727.8, \mathrm{R}^{2}=0.98 ;{ }^{\left[{ }^{4]}\right.} \hat{\mathrm{Y}}=-0.0002 \mathrm{x}^{2}+$ $0.1862 \mathrm{x}+640.83, \mathrm{R}^{2}=0.88$.

\subsection{Ruminal Parameters}

There was no effect $(P>0.05)$ of mesquite extract on the production of short-chain fatty acids (SCFA), acetic acid, butyric acid, molar ratio of butyric acid, ruminal $\mathrm{pH}$, ammonia nitrogen, rumen content, ruminal fluid density, turnover rate and disappearance rate (Table 3). Notwithstanding, the inclusion of mesquite extract in the diet of sheep caused quadratic responses $(P<0.05)$ in the production of propionic acid, molar ratio of acetic acid, molar ratio of propionic acid and acetic acid:propionic acid ratio (Table 3). The extract increased production of propionic acid with the concentration of $509 \mathrm{mg} / \mathrm{ml}$, the lowest molar ratio of acetic acid in the concentration of $504 \mathrm{mg} / \mathrm{ml}$, the highest molar ratio of propionic acid in the concentration of $505 \mathrm{mg} / \mathrm{ml}$ and the lowest acetate:propionate ratio in the concentration of $506 \mathrm{mg} / \mathrm{ml}$. 
Table 3. Ruminal parameters of sheep receiving mesquite pods extract

\begin{tabular}{|c|c|c|c|c|c|c|c|c|c|c|}
\hline \multirow{2}{*}{ Items } & \multicolumn{5}{|c|}{ Extract levels of mesquite pods $(\mathrm{mg} / \mathrm{mL})$} & \multirow{2}{*}{ S.E.M. } & \multirow{2}{*}{$\hat{\mathrm{Y}}$} & \multicolumn{3}{|c|}{ Polynomial contrasts } \\
\hline & 0 & 200 & 400 & 600 & 800 & & & $\mathrm{~L}$ & Q & $\mathrm{C}$ \\
\hline \multicolumn{11}{|l|}{ Production } \\
\hline $\operatorname{SCFA}(\mu \mathrm{m} / \mathrm{ml})$ & 37.83 & 38.5 & 38.48 & 40.8 & 38.85 & 1.02 & 38.88 & 0.64 & 0.75 & 0.58 \\
\hline Acetic acid & 28.8 & 28.2 & 27.03 & 27.3 & 28.41 & 0.72 & 27.9 & 0.40 & 0.44 & 0.76 \\
\hline Propionic acid & 6.71 & 8.03 & 9.04 & 9.94 & 8.13 & 0.49 & [1] & 0.02 & 0.01 & 0.16 \\
\hline Butyric acid & 2.32 & 2.26 & 2.41 & 2.59 & 2.31 & 0.13 & 2.37 & 0.65 & 0.71 & 0.42 \\
\hline \multicolumn{11}{|l|}{ Molar ratio } \\
\hline Acetic acid & 76.32 & 73.3 & 70.66 & 67.1 & 73.05 & 1.01 & [2] & 0.01 & 0.03 & 0.14 \\
\hline Propionic acid & 17.57 & 20.8 & 23.16 & 26.6 & 20.96 & 0.90 & [3] & 0.00 & 0.01 & 0.11 \\
\hline Butyric acid & 6.10 & 5.86 & 6.17 & 6.25 & 5.98 & 0.24 & 6.07 & 0.88 & 0.89 & 0.59 \\
\hline Acetate:propionate & 4.37 & 3.54 & 3.13 & 2.66 & 3.54 & 0.16 & {$[4]$} & 0.01 & 0.01 & 0.26 \\
\hline Ruminal pH & 6.07 & 6.02 & 6.14 & 6.07 & 6.08 & 0.02 & 6.07 & 0.63 & 0.68 & 0.48 \\
\hline N-ammoniated (mg/dl) & 5.76 & 5.79 & 6.52 & 5.20 & 6.47 & 0.18 & 5.94 & 0.94 & 0.80 & 0.12 \\
\hline \multicolumn{11}{|l|}{ Rumen contents (kg) } \\
\hline \multicolumn{11}{|l|}{ Dry matter } \\
\hline Before feeding & 0.96 & 0.99 & 1.00 & 0.95 & 0.84 & 0.04 & 0.95 & 0.37 & 0.39 & 0.91 \\
\hline After feeding & 1.36 & 1.17 & 1.22 & 1.38 & 1.39 & 0.05 & 1.30 & 0.47 & 0.26 & 0.32 \\
\hline \multicolumn{11}{|l|}{ Neutral detergent fiber } \\
\hline Before feeding & 0.33 & 0.33 & 0.34 & 0.31 & 0.28 & 0.01 & 0.32 & 0.37 & 0.44 & 0.91 \\
\hline After feeding & 0.45 & 0.37 & 0.39 & 0.46 & 0.46 & 0.02 & 0.42 & 0.47 & 0.23 & 0.26 \\
\hline \multicolumn{11}{|l|}{ Crude protein } \\
\hline Before feeding & 0.12 & 0.12 & 0.12 & 0.12 & 0.10 & 0.01 & 0.11 & 0.45 & 0.59 & 0.93 \\
\hline After feeding & 0.18 & 0.15 & 0.18 & 0.16 & 0.20 & 0.01 & 0.17 & 0.65 & 0.51 & 0.95 \\
\hline \multicolumn{11}{|l|}{ Density $\left(\mathrm{kg} / \mathrm{cm}^{3}\right)$} \\
\hline Before feeding & 0.84 & 0.87 & 0.89 & 0.88 & 0.89 & 0.01 & 0.87 & 0.10 & 0.27 & 0.63 \\
\hline After feeding & 0.93 & 0.90 & 0.91 & 0.93 & 0.92 & 0.01 & 0.92 & 1.00 & 0.46 & 0.15 \\
\hline \multicolumn{11}{|l|}{ Turnover rate } \\
\hline Dry matter $(\% / h)$ & 17.27 & 17.6 & 17.21 & 13.8 & 14.47 & 1.13 & 16.07 & 0.25 & 0.81 & 0.57 \\
\hline NDF (\%/h) & 11.12 & 10.3 & 10.36 & 8.34 & 8.53 & 0.76 & 9.74 & 0.19 & 0.99 & 0.80 \\
\hline Crude protein $(\% / h)$ & 17.93 & 18.1 & 15.59 & 13.7 & 14.21 & 1.59 & 15.89 & 0.30 & 0.93 & 0.67 \\
\hline \multicolumn{11}{|l|}{ Disappearance rate } \\
\hline Dry matter $(\% / h)$ & 6.74 & 5.77 & 6.22 & 8.42 & 7.36 & 0.43 & 6.90 & 0.21 & 0.67 & 0.13 \\
\hline NDF (\%/h) & 10.80 & 9.88 & 10.53 & 15.2 & 12.44 & 0.89 & 11.77 & 0.18 & 0.96 & 0.16 \\
\hline Crude protein $(\% / \mathrm{h})$ & 8.54 & 6.42 & 6.54 & 8.65 & 9.06 & 0.76 & 7.84 & 0.55 & 0.28 & 0.48 \\
\hline
\end{tabular}

Note. S.E.M. = Standard error mean; $\mathrm{L}=$ Linear; $\mathrm{Q}=$ Quadratic; $\mathrm{C}=$ Cubic; SCFA = Short-chain fatty acids; $\mathrm{NDF}=$ Neutral detergent fiber; ${ }^{[1]} \hat{\mathrm{Y}}=-0.00001318 \mathrm{x}^{2}+0.01342 \mathrm{x}+6.36651, \mathrm{R}^{2}=0.73 ;{ }^{[2]} \hat{\mathrm{Y}}=0.00003046 \mathrm{x}^{2}$ $-0.03072 \mathrm{x}+77.06057, \mathrm{R}^{2}=0.78 ;{ }^{[3]} \hat{\mathrm{Y}}=-0.00002993 \mathrm{x}^{2}+0.03023 \mathrm{x}+16.93381, \mathrm{R}^{2}=0.80 ;{ }^{[4]} \hat{\mathrm{Y}}=0.00000598 \mathrm{x}^{2}$ $-0.00605 x+4.43879, R^{2}=0.91$.

\subsection{Nitrogen Use Efficiency, Microbial Protein Synthesis and Ciliated Protozoa}

Nitrogen use efficiency was not affected $(P>0.05)$ by the mesquite extract (Table 4). Microbial nitrogen, microbial protein synthesis, microbial protein synthesis efficiency and number of ciliated protozoa in the rumen showed quadratic behavior $(P<0.05)$ with the inclusion of mesquite extract in the diet of sheep. Microbial nitrogen, microbial protein synthesis and microbial protein synthesis efficiency had greater values in the concentrations of 483,487 and $460 \mathrm{mg} / \mathrm{ml}$, respectively. The ciliated protozoa in the rumen showed lower counts in the concentration of $496 \mathrm{mg} / \mathrm{ml}$. 
Table 4. Nitrogen use efficiency, microbial protein synthesis and ciliated protozoa in sheep submitted to extract intake of mesquite pods

\begin{tabular}{|c|c|c|c|c|c|c|c|c|c|c|}
\hline \multirow{2}{*}{ Variables } & \multicolumn{5}{|c|}{ Extract levels (mg/mL) } & \multirow{2}{*}{$\hat{\mathrm{Y}}$} & \multirow{2}{*}{ S.E.M. } & \multicolumn{3}{|c|}{ Polynomial contrasts } \\
\hline & 0 & 200 & 400 & 600 & 800 & & & $\mathrm{~L}$ & Q & C \\
\hline \multicolumn{11}{|l|}{ Nitrogen (g/day) } \\
\hline Consumed & 29.09 & 30.83 & 30.37 & 29.71 & 30.46 & 30.09 & 1.148 & 0.62 & 0.91 & 0.32 \\
\hline Digested & 21.80 & 24.12 & 22.75 & 23.50 & 23.42 & 23.12 & 1.092 & 0.53 & 0.91 & 0.42 \\
\hline Excreted in feces & 7.29 & 6.70 & 6.94 & 6.21 & 7.04 & 6.83 & 0.276 & 0.66 & 0.38 & 0.66 \\
\hline Excreted in urine & 0.58 & 0.65 & 0.89 & 0.71 & 0.74 & 0.72 & 0.099 & 0.59 & 0.71 & 0.11 \\
\hline Retained & 21.21 & 23.05 & 21.86 & 22.78 & 22.68 & 23.32 & 1.079 & 0.57 & 0.94 & 0.58 \\
\hline Retained:ingested & 0.71 & 0.74 & 0.71 & 0.77 & 0.74 & 0.74 & 0.012 & 0.33 & 0.53 & 0.74 \\
\hline Microbial nitrogen & 7.51 & 8.65 & 10.90 & 10.77 & 8.92 & {$[1]$} & 0.538 & 0.20 & 0.05 & 0.44 \\
\hline Microbial protein & 46.93 & 54.07 & 68.13 & 67.30 & 55.78 & {$[2]$} & 3.360 & 0.20 & 0.05 & 0.44 \\
\hline MPSE (g/kg TDN) & 46.28 & 51.91 & 66.94 & 64.39 & 51.75 & [3] & 3.380 & 0.34 & 0.01 & 0.38 \\
\hline Protozoa $\left(\times 10^{4} / \mathrm{mL}\right)$ & 189.1 & 170.0 & 160.2 & 128.2 & 178.9 & [4] & 11.87 & 0.47 & 0.01 & 0.40 \\
\hline
\end{tabular}

\section{Discussion}

The presence of secondary plant compounds in the diet of ruminants can cause a number of disorders in the animal's metabolism, and can act directly on other body functions as the central nervous system (Ali, Tudsri, Rungmekarat, \& Kaewtrakulpong, 2012; Kingori, Odero-Waitituh, \& Guliye, 2011). However, the use of mesquite extract did not cause any effect on the nutrient intake and caused no changes in the behavioral patterns of the animals. This result is considered satisfactory, since the presence of secondary plant metabolites can affect the acceptability of the feed and consequently cause decreased consumption (Bonfim et al., 2012). NRC (2007) reported $1.15 \mathrm{~kg} /$ day of dry matter requirement for sheep with a $60 \mathrm{~kg}$ body weight and an average daily gain of $26 \mathrm{~g} /$ day. In this study, dry matter intake showed mean values of $1.31 \mathrm{~kg} /$ day, respectively (Table 2 ).

The ingestive behavior is influenced negatively by the presence of secondary plant metabolites, due to reduced palatability and digestibility of the diet. Gabbi, Moraes, Skonieski, and Viegas (2009) found changes in the behavior of heifers when fed with a phytogenic additive. Nevertheless, the way in which these secondary compounds were used in the present study was not sufficient to cause changes in the feeding behavior of sheep, which highlights the use of plant extracts as phytogenic additives.

The tannins found in the mesquite extract (Table 1) increased propionic acid production and microbial protein synthesis (Tables 3 and 4) and consequently increased flow to the small intestine. This increase in the microbial protein flow to the small intestine resulted in increased digestibility of crude protein and thus increased digestibility of dry matter, organic matter and total digestible nutrients (Table 3). The mesquite extract acted on Gram-positive bacteria, as these are more sensitive to the penetration of bioactive compounds, due to the absence of an outer membrane for protection, present only in Gram-negative bacteria (Thao, Wanapat, Kang, \& Cherdthong, 2015). With the reduction of the activity of Gram-positive bacteria by the action of the extract, the growth and degradation of feed by Gram-negative bacteria was favored. These bacteria have an increased rate of multiplication when compared to the Gram-positive ones.

Jayanegara, Goel, Makkar, and Becker (2015), Bodas et al. (2012), Durmic and Blache (2012) reported that the increase of Gram-negative bacteria decrease the acetate:propionate ratio, increase the microbial protein supply to the ruminant animal, due to its multiplication speed being more accelerated, besides other benefits such as the energy and higher supply use of dietary protein to the animal.

Patra and Saxena (2011) reported that ruminal Gram-positive bacteria have a low molecular weight, becoming more susceptible to the action of tannins; consequently, the inhibitory effect of tannins on these microorganisms would be greater. Francisco et al. (2015) and Morales and Ungerfeld (2015) reported that tannins antimicrobial properties have opened the possibility of using them to manipulate ruminal microbial activity in favorable directions, e.g. slow down protein digestion, increase microbial protein synthesis, decrease methanogenesis, modify fatty acids biohydrogenation and prevent bloat. Condensed tannins also have the ability to complex with 
enzymes, thereby causing changes in the microbial metabolism (Bodas et al., 2012; Mandal, Roy, \& Patra, 2014).

The increased microbial protein synthesis was also influenced by the reduction in the number of protozoa present in the rumen (Table 4). More specifically, the condensed tannins act directly on the cell wall of protozoa, causing cell lysis, leading to cell death. With this, the number of bacteria becomes greater, as the predation by protists, especially ciliates, also decreases; consequently, the feed degradation in the rumen becomes more efficient, due to the existence of a larger number of bacteria acting directly on the feed consumed (Bodas et al., 2012). García-González, González, and López (2010) and Anantasook, Wanapat, Cherdthong, and Gunun (2013) reported that the increase of Gram-negative bacteria improves the fermentation of nutrients in the rumen, consequently causing an increase in the digestibility of dry matter and organic matter.

The reduction in the Gram-positive bacteria population (major acetate producer), caused by the use of mesquite extract, led the reduced cofactors to be oxidized in the production of propionic acid during the fermentation of carbohydrates, stimulating increased propionic acid production in the rumen, as well as increased molar ratio of propionic acid, decreased molar ratio of acetic acid and decreased acetate:propionate ratio (Table 3), increasing the retention of energy by the animal and stimulating gluconeogenesis. Beauchemin, McGinn, Martinez, and McAllister (2007) and Castro-Montoya, Makkar, and Becker (2011) reported a reduction in the production of acetic acid and an increase in the production of propionic acid in ruminants fed with condensed tannins.

Normally, the increase in propionate production is associated with the addition of a concentrate in the diet and therefore decreased ruminal $\mathrm{pH}$. Nonetheless, the mesquite extract increased the production of such short-chain fatty acid without altering the ruminal $\mathrm{pH}$ (Table 3 ). The ammonia nitrogen can vary in a negative way when the tannins bind to the protein in the rumen, consequently reducing the release of ammonia nitrogen, however, in spite of the extract having condensed tannins in its constitution (Table 1), this characteristic did not alter the ammonia nitrogen content (Table 3) and did not impair the microbial protein synthesis (Table 4).

\section{Conclusion}

The use of mesquite extract at a concentration of $488 \mathrm{mg} / \mathrm{ml}$ is recommended to improve digestibility of dry matter, organic matter, crude protein and total digestible nutrients, in an effort to optimize microbial protein synthesis and increase propionic acid production.

\section{References}

Ali, A. S., Tudsri S., Rungmekarat, S., \& Kaewtrakulpong, K. (2012). Effect of feeding Prosopis juliflora pods and leaves on performance and carcass characteristics of afar sheep. Kasetsart Journal Natural Science, 881, 871-881.

Anantasook, N., Wanapat, M., Cherdthong, A., \& Gunun, P. (2013). Changes of microbial population in the rumen of dairy steers as influenced by plant containing tannins and saponins and roughage to concentrate ratio. Asian-Australasian Journal of Animal Science, 26(11), 1583-1591. https://doi.org/10.5713/ajas.2013. 13182

AOAC. (1990). Official methods of analysis (15th ed.). Arlington, V.A., Association of Official Analytical Chemists.

Beauchemin, K. A., McGinn, S. M., Martinez, T. F., \& McAllister, T. A. (2007). Use of condensed tannin extract from quebracho trees to reduce methane emissions from cattle. Journal of Animal Science, 85(4), 1990-1996. https://doi.org/10.2527/jas.2006-686

Bodas, R., Prieto, N., García-González, R., Andrés, S., Giráldez, F. J., \& López, S. (2012). Manipulation of rumen fermentation and methane production with plant secondary metabolites. Animal Feed Science and Technology, 176(1-4), 78-93. https://doi.org/10.1016/j.anifeedsci.2012.07.010

Bonfim, M. A. D., Barcelos, D. G., Facó, O., Oliveira, L. S., Gonsalves, J. L., Oliveira, K. S., \& Ferreira, A. M. F. (2012). Consumo e produção de leite de cabras alimentadas com pedúnculo de caju e níveis crescentes de óleo de soja. Revista Científica de Produção Animal, 14(1), 85-88. https://doi.org/10.15528/2176-4158/ rcpa.v14n1p85-88

Cannas, A., Van Soest, P. J., \& Pell, A. N. (2003). Use of animal and dietary information to predict rumen turnover. Animal Feed Science and Technology, 106(1-4), 95-117. https://doi.org/10.1016/S0377-8401 (02)00255-9

Carvalho, V. V., Paulino, M. F., Detmann, E., Chizzotti, M. L., Martins, L. S., Silva, A. G., ... Moura, F. H. (2017). Effects of supplements containing different additives on nutritional and productive performance of 
beef cattle grazing tropical grass. Tropical Animal Health and Production, 49(5), 983-988. https://doi.org/ $10.1007 / \mathrm{s} 11250-017-1286-8$

Castillejos, L., Calsamiglia, S., Martín-Tereso, J., \& Wijlen, H. T. (2008). In vitro evaluation of effects of ten essential oils at three doses on ruminal fermentation of high concentrate feedlot-type diets. Animal Feed Science and Technology, 145(1-4), 259-270. https://doi.org/10.1016/j.anifeedsci.2007.05.037

Castro-Montoya, J. M., Makkar, H. P. S., \& Becker, K. (2011). Chemical composition of rumen microbial fraction and fermentation parameters as affected by tannins and saponins using an in vitro rumen fermentation system. Canadian Journal of Animal Science, 91(3), 433-448. https://doi.org/10.1139/CJAS 2010-028

Chen, X. B., \& Gomez, M. J. (1992). Estimation of microbial protein supply to sheep and cattle based on urinary excretion of purine derivatives. An overview of technical details. International Feed Resource Unit. Occasional Publication. Rowet Research Institute, Bucksburn, Aberdeen, UK. Retrieved from https://www.researchgate.net/profile/M_Gomes4/publication/265323654_Estimation_of_Microbial_Protein

D'Agosto, M., \& Carneiro, M. E. (1999). Evaluation of lugol solution used for counting rumen ciliates. Revista Brasileira de Zoologia, 16(3), 725-729. https://doi.org/10.1590/S0101-81751999000300011

Dehority, B. A. (1984). Evaluation of subsampling and fixation procedures used for counting rumen protozoa. Applied and Environmental Microbiology, 48(1), 182-185.

Durmic, Z., \& Blache, D. (2012). Bioactive plants and plant products: Effects on animal function, health and welfare. Animal Feed Science and Technology, 176(1-4), 150-162. https://doi.org/10.1016/j.anifeedsci.2012. 07.018

Durmic, Z., McSweeney, C. S., Kemp, G. W., Hutton, P., Wallace, R. J., \& Vercoe, P. E. (2008). Australian plants with potential to inhibit bacteria and processes involved in ruminal biohydrogenation of fatty acids. Animal Feed Science and Technology, 145(1-4), 271-284. https://doi.org/10.1016/j.anifeedsci.2007.05.052

Fenner, H. (1965). Methods for determining total volatile bases in rumen fluid by steam distillation. Jornal of Dairy Science, 48(2), 249-251. https://doi.org/10.3168/jds.S0022-0302(65)88206-6

Flachowsky, G., \& Lebzien, P. (2012). Effects of phytogenic substances on rumen fermentation and methane emissions: A proposal for a research process. Animal Feed Science and Technology, 176(1-4), 70-77. https://doi.org/10.1016/j.anifeedsci.2012.07.009

Francisco, A., Dentinho, M. T., Alves, S. P., Portugal, P. V., Fernandes, F., Sengo, S., ... Santos-Silva, J. (2015). Growth performance, carcass and meat quality of lambs supplemented with increasing levels of a tanniferous bush (Cistus ladanifer L.) and vegetable oils. Meat Science, 100(1), 275-282. https://doi.org/10.1016/j.meatsci.2014.10.014

Gabbi, A. M., Moraes, R. S., Skonieski, F. R., \& Viegas, J. (2009). Desempenho produtivo e comportamento de novilhas submetidas a dietas com aditivo fitogênico. Revista Brasileira de Saúde e Produção Animal, 10(4), 949-962.

García-González, R., González, J. S., \& López, S. (2010). Decrease of ruminal methane production in Rusitec fermenters through the addition of plant material from rhubarb (Rheum spp.) and alder buckthorn (Frangula alnus). Journal of Dairy Science, 93(8), 3755-3763. https://doi.org/10.3168/jds.2010-3107

Hall, M. B. (2000). Calculation of non-structural carbohydrate content of feeds that contain non-protein nitrogen (Bulletin, 339, pp. 25-34). Gainesville: University of Florida.

INMET. (2014). Parâmetros Meteorológicos de Serra Talhada. Instituto Nacional de Meteorologia. Retrieved from http://www.inmet.gov.br

Jayanegara, A., Goel, G., Makkar, H. P. S., \& Becker, K. (2015). Divergence between purified hydrolysable and condensed tannin effects on methane emission, rumen fermentation and microbial population in vitro. Animal Feed Science and Technology, 209(11), 60-68. https://doi.org/10.1016/j.anifeedsci.2015.08.002

Kingori, A. M., Odero-Waitituh, J. A., \& Guliye, A. Y. (2011). Mathenge (Prosopis juliflora): An underutilized livestock feed resource in Kenya. Research Journal of Animal Science, 5(4), 43-51. https://doi.org/10.3923/ rjnasci.2011.43.51

Mandal, G. P., Roy, A., \& Patra, A. K. (2014). Effects of feeding plant additives rich in saponins and essential oils on the performance, carcass traits and conjugated linoleic acid concentrations in muscle and adipose 
tissues of Black Bengal goats. Animal Feed Science and Technology, 197(11), $76-84$. https://doi.org/10.1016/j.anifeedsci.2014.08.008

Morales, R., \& Ungerfeld, E. M. (2015). Use of tannins to improve fatty acids profile of meat and milk quality in ruminants: A review. Chilean Journal of Agricultural Research, 75(2), 239-248. https://doi.org/10.4067/ S0718-58392015000200014

Nisbet, D. J., Callaway, T. R., Edrington, T. S., Anderson, R. C., \& Krueger, N. (2009). Effects of the dicarboxylic acids malate and fumarate on E. coli $\mathrm{O} 157: \mathrm{H} 7$ and salmonella enterica typhimurium populations in pure culture and in mixed ruminal microorganism fermentations. Current Microbiology, 58(11), 488-492. https://doi.org/10.1007/s00284-008-9351-1

NRC. (2007). Nutrient Requirements of Small Ruminants: Sheep, Goats, Cervids, and New World Camelids. Washington, D.C., National Academy Press.

Oskoueian, E., Abdullah, N., \& Oskoueian, A. (2013). Effects of flavonoids on rumen fermentation activity, methane production, and microbial population. Biomed Research International, 2013, 1-8. https://doi.org/ $10.1155 / 2013 / 349129$

Patra, A. K., \& Saxena, J. (2011). Exploitation of dietary tannins to improve rumen metabolism and ruminant nutrition. Journal of the Science of Food and Agriculture, 91(1), 24-37. https://doi.org/10.1002/jsfa.4152

SAS. (2009). SAS User's Guide: Statics. SAS Institute Inc.

Sniffen, C. J., O’Connor, J. D., Van Soest, P. J., Fox, D. G., \& Russell, J. B. (1992). A net carbohydrate and protein system for evaluating cattle diets: II. Carbohydrate and protein availability. Journal of Animal Science, 70(11), 3562-3577. https://doi.org/10.2527/1992.70113562x

Terrill, T. H., Rowan, A. M., Douglas, G. B., \& Barry, T. N. (1992). Determination of extractable and bound condensed tannin concentrations in forage plants, protein concentrate meals and cereal grains. Journal of the Science of Food and Agriculture, 58(3), 321-329. https://doi.org/10.1002/jsfa.2740580306

Thao, N. T., Wanapat, M., Kang, S., \& Cherdthong, A. (2015). Effects of supplementation of eucalyptus (E. camaldulensis) leaf meal on feed intake and rumen fermentation efficiency in swamp buffaloes. Asian-Australasian Journal of Animal Science, 28(7), 951-957. https://doi.org/10.5713/ajas.14.0878

Van Soest, P. J., Robertson, J. B., \& Lewis, B. A. (1991). Methods for dietary fiber, neutral detergent fiber, and nonstarch polysaccharides in relationn to animal nutrition. Journal of Dairy Science, 74(10), 3583-3597. https://doi.org/10.3168/jds.S0022-0302(91)78551-2

Weiss, W. P. (1999). Energy prediction equations for ruminant feeds. Proceedings of Cornell nutrition conference for feed manufacturers, 61 (pp. 176-185). Ithaca: Cornell University.

William, K., \& Jafri, L. (2015). Mesquite (Prosopis juliflora): Livestock grazing, its toxicity and management. Journal of Bioresource Managmente, 2(1), 49-58.

\section{Copyrights}

Copyright for this article is retained by the author(s), with first publication rights granted to the journal.

This is an open-access article distributed under the terms and conditions of the Creative Commons Attribution license (http://creativecommons.org/licenses/by/4.0/). 